\title{
Persistent Pollutants in Audouin's Gull (Larus audouinii) in the Western Mediterranean: A Case-study with Wide Implications?
}

\author{
by
}

M. F. I. J. BIJLEVELD, Ph.D. (Amsterdam Free University)

Programme Officer, IUCN, 1110 Morges, Switzerland,

P. GOELDLIN, Ph.D. (Lausanne)

Zoological Museum, Lausanne, Switzerland,

$\&$

\section{J. MAYOL}

Grupo Ornitologia Balear, Palma de Mallorca, Spain.

\section{INTRODUCTION}

The world population of the rare and specialized Audouin's Gull (Larus audouinii) is restricted to the Mediterranean region (Voous, 1960) and is now estimated to number only about 2,000 pairs, of which the western Mediterranean harbours some $80 \%$. Although an increase appears to have occurred in the latter area in recent years (Mayol, 1978), the species is rightly included in the IUCN Red Data Book (Figs. 1 \& 2).

In 1978 a survey of the species was carried out in the framework of project No. 1413 in the conservation programme of the International Union for Conservation of
Nature and Natural Resources (IUCN), the World Wildlife Fund (WWF), and the International Council for Bird Preservation (ICBP). During this survey, some eggs that had not hatched were collected and their contents were analysed at the Cantonal Laboratory of the Canton de Vaud, Epalinges, Switzerland. The shells have been deposited in the Zoological Museum, Lausanne.

\section{METHODS}

Three of the unhatched eggs of Audouin's Gull were collected in the southern Mediterranean region off the

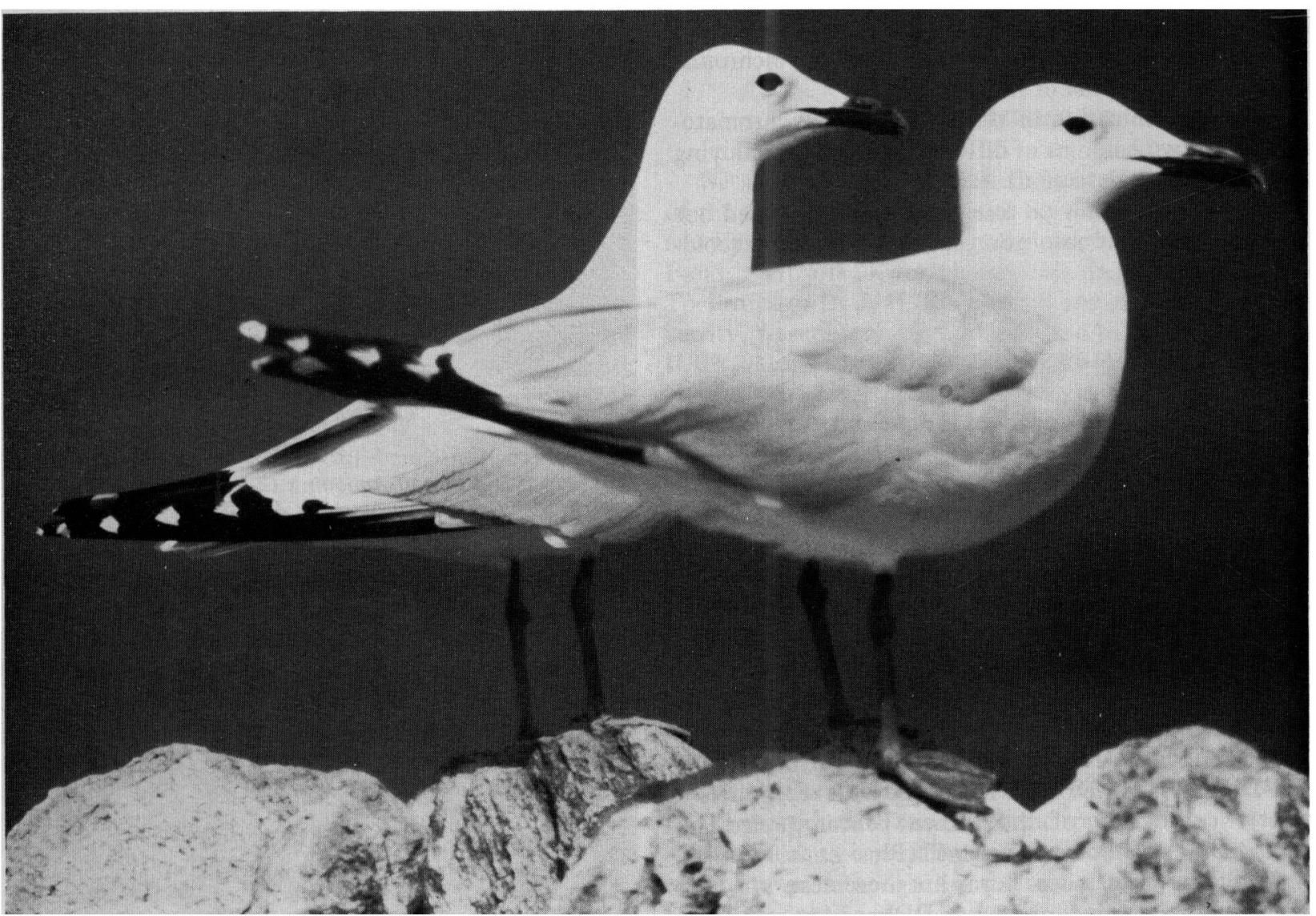

Fig. 1. Adult Audouin's Gulls (Larus audouinii). Total length (tip of bill to tail) $49 \mathrm{~cm}$. Photo: Helmar Schenk. 


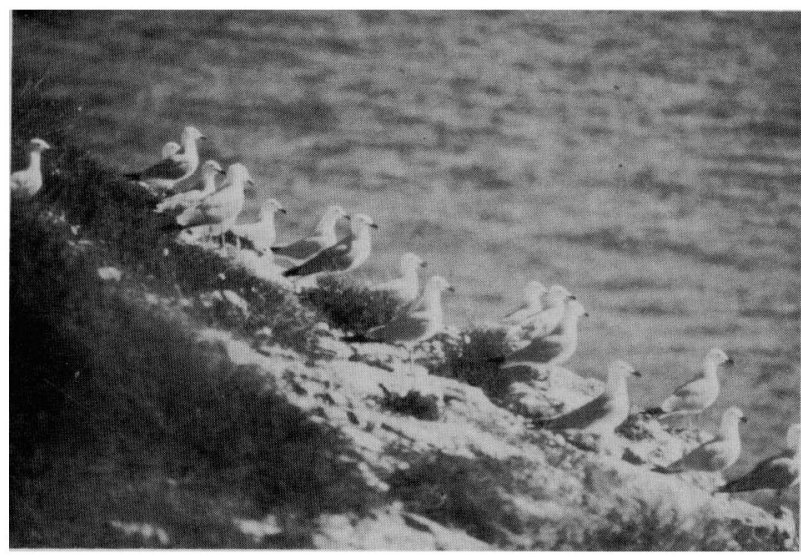

Fig. 2. Flock of adult Audouin's Gulls on an island off the coast of Morocco. Photo: Joan Mayol.

Moroccan coast, the other four being collected in the northern Mediterranean-in the Balearic Islands, where also were collected one unhatched egg each of the Mediterranean Herring Gull (Larus argentatus michahellis) and the Black Vulture (Aegypius monachus). Only addled eggs that had failed to hatch were taken, and therefore these do not constitute an unbiased sample.

The qualitative and quantitative analyses of organochlorine insecticide and polychlorobiphenyl residues have been accomplished through:

a) Extraction from samples by employing the method of Langlois et al. (1964);

b) Clean-up of the extracts by absorptive chromatography on a column of florisil; and

c) Determination of the residues by gas chromatography on two columns of different polarities employing electron capture detection.

The determination of total mercury was carried out by flameless atomic absorption spectrophotometry (coldvapour system).

\section{RESULTS AND DISCUSSION}

The results of the analyses are presented in Table I. Chemicals detected included mercury, DDE (dichlorophenyl-dichloroethylene), PCBs (polychlorinated biphenyls), HCB (hexachlorobenzene), dieldrin, and HE (heptachlor-epoxide). On average, levels were lowest for dieldrin, heptachlor-epoxide, and hexachlorobenzene. The difference between average levels of DDE, PCBs, and mercury, in Audouin's Gulls in the northern and southern parts of the western Mediterranean, is striking. DDE levels averaged from $1.94 \mathrm{ppm}$ in the south to $3.67 \mathrm{ppm}$ in the north.

A strong correlation was found between the amount of DDE (metabolite of DDT) in eggs with reproductive success or decline of the Brown Pelican (Pelecanus occidentalis) in South Carolina (Blus et al., 1974). Reproductive success was normal in those nests in which sample eggs contained $2.5 \mathrm{ppm}$ DDE or less, while in those with eggs exceeding that level no downy young were produced (Ibid.). Similar relationships were found in Ospreys (Pandion haliaëtus) in Connecticut at average levels of $8.9 \mathrm{ppm}$ DDE in sample eggs, whereas Ospreys in Maryland hatched normally at an average level of $2.4 \mathrm{ppm}$ DDE in sample eggs (Wiemeyer et al., 1975). Lincer (1975) came to similar conclusions with regard to the American Kestrel (Falco sparverius). Koeman et al. (1972) concluded that DDE was most likely to be the major cause of the lack of reproductive success in Sea Eagles (Haliaëtus albicilla) in Schleswig-Holstein, Federal Republic of Germany, where an average of 10.12 ppm DDE has been found in eggs that did not hatch.

The average levels of pollutants found in the southern part of the western Mediterranean region still seem to fall within the range where normal reproduction can be expected (cf. Figs. $3 \& 4$ ).

Although the failures of hatching may have resulted from disturbance or some other cause, the average level found-especially in the north of the western Mediterranean, where maximum levels reach $4.15 \mathrm{ppm}$ and 5.44 $\mathrm{ppm}$ - give reason for concern as they approach, or have already reached, the level where only diminished reproduction can take place. In this context, the fact that two of the sample eggs from the northern Mediterranean contained embryos may have some significance (cf. Blus et al., 1974).

Average levels of PCBs also appear to be much higher in the northern than in the southern part of the western

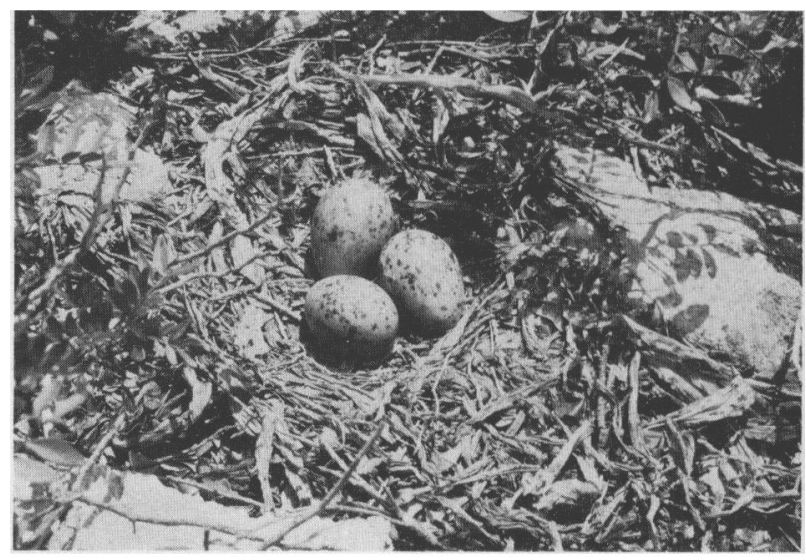

Fig. 3. Nest and eggs of Audouin's Gull (Larus audouinii) on a Balearic island. Eggs approx. $62 \times 43 \mathrm{~mm}$. Photo: Joan Mayol.

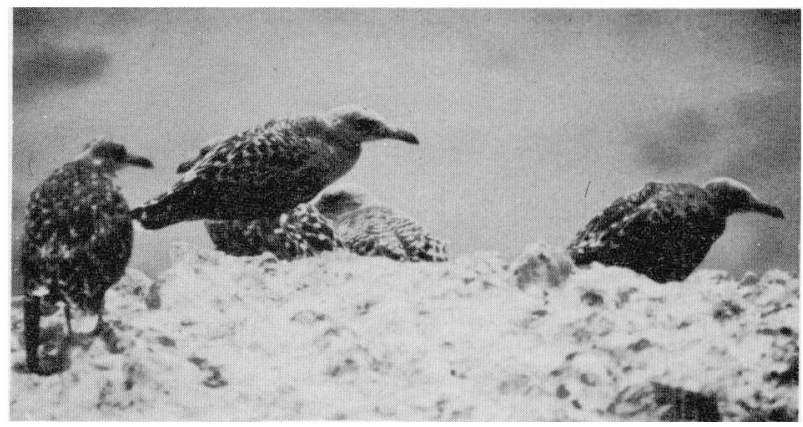

Fig. 4. Audouin's Gulls (Larus audouinii) in first-year plumage. These specimens are not yet fully grown. Photo: Xese Moll. 
TABLE I. Residues of Organochlorine Pesticides, PCBs, and Mercury, in Eggs of Audouin's Gull, Herring Gull, and Black Vulture, 1978.

\begin{tabular}{|c|c|c|c|c|c|c|c|c|}
\hline \multirow[t]{2}{*}{ Species } & \multirow[t]{2}{*}{ Collection area } & \multicolumn{6}{|c|}{ Residue concentration ppm (net-weight) } & \multirow[t]{2}{*}{ Remarks } \\
\hline & & $D D E$ & Dieldrin & $H E$ & $H C B$ & $P C B$ & $H g$ & \\
\hline \multirow[t]{2}{*}{$\begin{array}{l}\text { Larus audouinii } \\
\text { Larus audouinii } \\
\text { Larus audouinii }\end{array}$} & $\begin{array}{l}\text { Chafarinas Islands } \\
\text { Chafarinas Islands } \\
\text { Chafarinas Islands }\end{array}$ & $\begin{array}{l}1.02 \\
1.95 \\
2.84\end{array}$ & $\begin{array}{l}0.046 \\
0.078 \\
0.050\end{array}$ & $\begin{array}{l}\operatorname{tr} .^{*} \\
0.013 \\
\text { ndt }\end{array}$ & $\begin{array}{l}0.028 \\
0.034 \\
0.027\end{array}$ & $\begin{array}{l}3.1 \\
4.2 \\
4.2\end{array}$ & $\begin{array}{l}0.70 \\
0.63 \\
0.95\end{array}$ & \\
\hline & Average & 1.94 & 0.058 & & 0.030 & 3.82 & 0.76 & \\
\hline \multirow[t]{2}{*}{$\begin{array}{l}\text { Larus audouinii } \\
\text { Larus audouinii } \\
\text { Larus audouinii } \\
\text { Larus audouinii }\end{array}$} & $\begin{array}{l}\text { Balearic Islands } \\
\text { Balearic Islands } \\
\text { Balearic Islands } \\
\text { Balearic Islands }\end{array}$ & $\begin{array}{l}2.20 \\
5.44 \\
2.90 \\
4.15\end{array}$ & $\begin{array}{l}0.104 \\
0.138 \\
0.130 \\
0.120\end{array}$ & $\begin{array}{l}0.031 \\
\mathrm{nd}^{\dagger} \\
0.029 \\
0.023\end{array}$ & $\begin{array}{l}0.055 \\
0.085 \\
0.158 \\
0.080\end{array}$ & $\begin{array}{l}12.8 \\
20.6 \\
16.0 \\
17.6\end{array}$ & $\begin{array}{l}0.87 \\
1.00 \\
1.39 \\
1.22\end{array}$ & $\begin{array}{l}\text { embryonated } \\
\text { embryonated }\end{array}$ \\
\hline & Average & 3.67 & 0.123 & 0.021 & 0.09 & 16.75 & 1.12 & \\
\hline Larus argentatus subsp. michahellis & Balearic Islands & 3.55 & 0.062 & 0.007 & 0.053 & 11.0 & 1.20 & \\
\hline Aegypius monachus & Balearic Islands & 0.20 & $\mathrm{nd}^{\dagger}$ & 0.008 & 0.012 & 0.4 & 0.15 & \\
\hline
\end{tabular}

*tr. $=$ trace. + nd $=$ not determined.

Mediterranean, being $16.75 \mathrm{ppm}$ and $3.82 \mathrm{ppm}$, respectively. In general, however, there are no indications as yet that PCBs are involved in any reduction of reproduction in birds. The levels found are relatively low in comparison with some of those found for example in North German Sea Eagles (Koeman et al., 1972; Blus et al., 1974).

Dieldrin levels ranging from averages of $0.058 \mathrm{ppm}$ in the south to $0.123 \mathrm{ppm}$ in the north can be regarded as too low to influence reproductive success. Blus et al. (1974) found that reproduction in the Brown Pelican was still normal in eggs containing $<0.54 \mathrm{ppm}$ of dieldrin.

As could be expected, lower levels of mercury (average $0.76 \mathrm{ppm}$ ) were found in the south of the western Mediterranean than in the northern portion $(1.12 \mathrm{ppm})$. However, these levels are not likely to influence reproductive success (J. H. Koeman, 1979 pers. comm).

The levels of residues of organochlorine pesticides found in an egg of the Mediterranean Herring Gull in the Balearic Islands equal the average level of DDE found in the eggs of Audouin's Gull, whilst levels of dieldrin, $\mathrm{HE}, \mathrm{HCB}$, and PCBs, are considerably lower-a fact that may be related to Audouin's Gull being more exclusively a fish-eating species.

The analysis of the contents of an unhatched egg of the Black Vulture from the Balearic Islands revealed extremely low levels of all organochlorine compounds and of mercury. The hatching failure of this egg is therefore likely to be due to other factors. The extreme differences found between levels in this terrestrial species and the two marine species, all of them placed at the end of foodchains, well illustrate the contamination of the marine environment.

\section{CONCLUSION}

The levels of DDE found in the eggs of Audouin's Gull, especially in the western Mediterranean, give reason for concern about the reproductive success of the species, which could be impeded by further contamination of this marine environment by DDT. These findings- the first that are known to us on marine birds' eggs in the Mediterranean-complement similar findings of hifh levels of organochlorine compounds in a wide variety of species elsewhere in the Mediterranean (CIESM [Commission internationale pour l'exploration scientifique de la Méditerranée] , 1979).

\section{ACKNOWLEDGEMENTS}

We are indebted to Drs A. Etournaud and A. Ramuz, of the Cantonal Laboratory of the Canton de Vaud, for carrying out the analyses, and to the World Wildlife Fund, Switzerland, for making this financially possible. To Professor Dr J. H. Koeman, of the Agricultural University, Wageningen, Netherlands, and to Dr P. Hunkeler, IUCN, Morges, Switzerland, we are grateful for their helpful advice given on reading an earlier draft of the manuscript.

\section{SUMMARY}

The possibility of persistent pollutants playing an adverse role in the reproductive success of Audouin's Gull in the western Mediterranean was examined through chemical analyses of 7 eggs of this species that did not hatch. Residues of organochlorine compounds and mercury were found.

The conclusion has been reached that a further increase of present levels of DDE may well lead to a decline of the reproductive success of the species in the western Mediterranean, especially in the northern part. These observations, although limited, could have implications for further species as is already indicated by other work cited. 


\section{REFERENCES}

BLUS, L. J., NEELY, B. S., BELISLE, A. A. \& PROUTY, R. M. (1974). Organochlorine residues in Brown Pelican eggs: Relation to reproductive success. Environ. Pollut., 7, pp. $81-91$.

CIESM. (1979). IVes Journées d'Etude sur les Pollutions Marines en Méditerranée. Workshop on Pollution of the Mediterranean, Antalya, 24-27 November 1978. Commission internationale pour l'exploration scientifique de la Méditerranée, Monaco: $681 \mathrm{pp}$.

KOEMAN, J. H., HADDERINGH, R. H. \& BIJLEVELD, M. F. I. J. (1972). Persistant pollutants in the White-tailed Eagle (Haliaëtus albicilla) in the Federal Republic of Germany. Biol. Conser., 4 (5), pp. 373-7.
LANGLOIS, B, E., STEMPAR, A. R. \& LISTA, B. J. (1964). Rapid clean-up of dairy products for analysis of chlorinated insecticide residue by electron capture gas chromatography. J. Agr. Food Chem., 12, p. 243.

LINCER, J. L. (1975). DDE-induced eggshell-thinning in the American Kestrel: A comparison of the field situation and laboratory results. J. Appl. Ecol., 12, pp. 781-93.

MAYOL, J. (1978). Las Colonias de Gaviota de Audouin en el Mediterraneo occidental en 1978. Stencilled report, IUCN, 1110 Morges, Switzerland: $32 \mathrm{pp}$.

VOOUS, K.H. (1960). Atlas of European Birds. Nelson, London, U.K.: 284 pp., illustr.

WIEMEYER, S. N., SPITZER, P. R., KRANTZ, W. C., LAMONT, T. G. \& CROMARTIE, E. (1975). Effects of environmental pollutants on Connecticut and Maryland Ospreys. J. Wildl. Manage., 39 (1), pp. 124-39.

\section{International Effort to Study Causes of Monsoons}

The largest scientific venture ever undertaken jointly between the United States and South-east Asia has been launched as part of a year-long effort to determine what causes the erratic behaviour of monsoons that are apt to devastate large areas of the world. One goal of the international project is to hasten the day when scientists will be able to forecast monsoons accurately - a capability which has been described as among mankind's most important single predictions.

The project, called 'MONEX' for monsoon experiment, was started on 1 December 1978 in Kuala Lumpur, the capital of Malaysia. The US portion of the project is being coordinated by the National Science Foundation (NSF) and is considered a major expression of goodwill between the US and the South-east Asian countries where the winter phase of MONEX is being concentrated. Other US agencies taking part in the project are the National Oceanic and Atmospheric Administration (NOAA) and the National Aeronautics and Space Administration (NASA).

Monsoons, which vary in time and intensity from year to year, can bring life-giving rains or cause devastating droughts in South-east Asia and West Africa. They are the basis for the rich agriculture of this vast region and a major factor in the feeding of hundreds of millions of people who inhabit the area. The improved forecasts which may result from this project could be of special benefit to farmers and fishermen, enabling the former to make suitable decisions on when to plant their seeds or to harvest their crops (e.g. avoiding inclement weather conditions that could affect yields), ${ }^{*}$ while the latter would be able to plan their voyages on the open seas with a minimum of risks of encountering bad storms.

The behaviour of large-scale Asiatic monsoons is linked to global circulations which bring weather and possibly weather anomalies to the United States. A better knowledge of the Asian monsoon as a major regional energy source is essential to an improved understanding of global weather and climate. Extended forecasts over all areas of the world are probably not possible without detailed knowledge of the weather in the tropics and its wide-ranging effects. In addition to the United States and Malaysia, almost every country in South-east Asia is participating in the project.
Because of the natural division of the monsoon into a winter and a summer phase, and because of the regional distinctions in the monsoon between the eastern and Western regions of Asia, two separate efforts are required - a winter MONEX and a summer MONEX. The summer phase is scheduled to start on 1 May 1979 and to continue for four months, with its activities centred at New Delhi, India. Both efforts are designed to obtain a more comprehensive understanding of the regional and seasonal fluctuations of the Asian monsoon, and of its effect on global atmospheric circulation, than has hitherto been available.

For these purposes, ships and aircraft will gather data from an area of some 74 million square kilometres over the Indian Ocean, Arabian Sea, the Bay of Bengal, Southeast Asia, and the South China Sea. In addition, MONEX scientists will get data from two geostationary weather satellites, one of which is being provided earily in 1979 over the Indian Ocean in a cooperative effort by the NSF, NOAA, and NASA, while the other has already been made operational to the south of Japan by the Japanese.

MONEX is one of three regional experiments organized within the framework of the Global Weather Experiment: the other two are the West African Monsoon Experiment and the Polar Experiment. The Global Weather Experiment, in which more than 140 nations are participating, is part of the Global Atmospheric Research Programme, a joint effort of the World Meteorological Organization and the International Council of Scientific Unions. The Global Weather Experiment is a year-long international programme of research and data-gathering whose ultimate goal is to make possible longer-range weather predictions and to study the underlying causes of climate changes.

Ralph Kazarian
National Science Foundation
1800 G Street
Washington
D.C. 20550
USA.

*A referee points out the importance here of "policy on acquisition, storage, and import'.-Ed. 